Joanna Godlewicz-Adamiec

Warszawa

\title{
JEDEN KRAJ - WIELE KULTUR? SPOJRZENIE NA NIEMIECKĄ KULTURĘ W XXI WIEKU OCZAMI HÜLJI KALKAN
}

\section{Wprowadzenie}

Na niemieckim, a także polskim rynku wydawniczym, popularne stały się w XXI wieku wspomnienia i autobiograficzne relacje młodych muzułmanek $^{1}$, opowiadające $\mathrm{w}$ pierwszej osobie o poniżeniu, cierpieniach, ale też nadziejach na przyszłość. Książki tego typu pełnić mogą, podobnie jak już pod koniec wieków średnich u Christine de Pizan², funkcję terapeutyczną ${ }^{3}$ Książki te napisane są często przy pomocy dziennikarzy, część z nich z powodu lęku przez zemstą ze strony rodziny pod pseudonimem. Książki te są według „Spiegla” (33/2005) bardzo poczytne, osiągają wielotysięczne nakłady. Kobiety, które dzielą się swoimi przeżyciami i przemyśleniami pochodzą z różnych krajów, ich udziałem stały się różne doświadczenia. Nura Abdi, Somalijka, opisująca swoje wspomnienia w książce „Łzy na piasku” („Tränen im Sand”) to dziewczyna, która zbiegła do Niemiec i dopiero tu, w obozie azylantów, zrozumiała, że różni się od kobiet europejskich, a także, iż nawet nie wszystkie muzułmanki są obrzezane. Quarda Saillo w swojej książce „Księżyc wełzach” („Tränenmond: Ich war fünf, als meine

${ }^{1}$ Wyróżnić można muzułmanów religijnych, kulturowych i etnicznych (zob. K. Pędziwiatr, Od islamu imigrantów do islamu obywateli: muzutmanie w krajach Europy Zachodniej, Kraków 2007, s. 67).

${ }^{2}$ Christine de Pizan nie doświadczała przemocy, lecz przeżywała głęboką żałobę, a nawet traumę związaną ze śmiercią męża (zob. J. Besala, Miłość i strach. Dzieje uczuć kobiet i mężczyzn, t. 3, Chrześcijański feudalizm i islamskie haremy, Warszawa 2012, s. 334). Jednak także $\mathrm{w}$ tym przypadku pisanie pełniło między innymi rolę uporania się z przeżyciami.

${ }^{3}$ J. Besala, Miłość $i$ strach. Dzieje uczuć kobiet $i$ mężczyzn, t. 3, Chrześcijański feudalizm $i$ islamskie haremy, Warszawa 2012, s. 336. 
Kindheit starb”) opisuje przemoc w rodzinie. „Chciałam być tylko wolna. Moja ucieczka przed przymusowym ślubem” („Ich wollte nur frei sein. Meine Flucht vor der Zwangsehe") Hülji Kalkan to wzruszająca i wstrząsająca książka Niemki tureckiego pochodzenia. Kalkan po latach spisała swoje wspomnienia dotyczące kwestii małżeństwa z przymusu i historię wywiezienia z Turcji do Niemiec własnej siostry (2002).

Kalkan popularyzuje wiedzę na temat przymusowego małżeństwa, spotykając się z młodzieżą, uświadamiając nauczycielom i szkolnym pedagogom gdzie nagle znikają ich uczennice ${ }^{4}$. Według raportu niemieckiego ministerstwa przedstawionego przez minister do spraw rodziny Kristinę Schröder rocznie ponad 3000 kobiet w Niemczech zmuszanych jest do małżeństwa. Wiele z nich pochodzi z religijnych rodzin ${ }^{5}$. Według ministra spraw wewnętrznych Hansa Petera Friedricha małżeństwa przymusowe i przemoc $\mathrm{w}$ rodzinie nie mają podłoża $\mathrm{w}$ islamie, lecz są wynikiem patriarchalnych struktur ${ }^{6}$. Porwania występowały w Europie jako strategia matrymonialna, były stosowane $\mathrm{w}$ wielu kulturach i zdarzają się obecnie miedzy innymi na Sycylii lub wśród Romów ${ }^{7}$.

Wiele z kobiet, opisujących swoje wspomnienia, związanych jest emocjonalnie z Niemcami, które niejednokrotnie postrzegają jako swoją drugą lub jedyną ojczyznę, a ich wspomnienia są nie tylko refleksją lub wręcz rozrachunkiem z tradycją, kulturą rodziców, ale także tekstami zawierającymi wnikliwe, chociaż subiektywne obserwacje na temat życia w Niemczech. Do książek podejmujących kwestie funkcjonowania ze sobą lub obok siebie w Niemczech kultur i religii oraz współistnienia i tworzenia równoległych społeczeństw należy „Chciałam być tylko wolna” Hülji Kalkan.

„W pamięci mam przystań, w której dawno, dawno temu mieszkało szczęście”8 - zielone wzgórza Rielingshausen

Leżące w Badenii-Wirtembergii zielone wzgórza Rielingshausen, zapamiętane z dzieciństwa, jawią się Hülji jako przystań - symbol wolności i szczęścia. Dziewczynka czuła się wówczas wolna, zapominała o kło-

${ }^{4}$ www.bilderstrom.de/cms/fritz-winter-gesamtschule/index.php?id=402\&no_cache $=1 \&$ th_ttnews\%5Btt_news\%5D... (15 listopada 2012).

${ }^{5}$ www.zeit.de/gesellschaft/2011-11/zwangsehe-studie-migrantinnen (15 listopada 2012).

${ }^{6}$ www.deutsch-tuerkische-nachrichten.de/2012/04/452174/friedrich-\%e2\%80\%9 ezwangsheirat-hat-nichts-mit-dem-... (15.11.20102).

7 M. Malinowska, Sytuacja kobiety w siedemnastowiecznej Francji i Polsce, Warszawa 2008, s. 26.

${ }^{8} \mathrm{H}$. Kalkan, Chciałam być tylko wolna. Moja ucieczka przed przymusowym ślubem, Tczew 2011, s. 6. 
potach i obowiązkach, takich jak opieka nad młodszym rodzeństwem: „W pamięci mam przystań, w której dawno, dawno temu mieszkało szczęście. Małe szczęście ośmioletniej dziewczynki, którą kiedyś byłam”"9. Z perspektywy małego dziecka różnice kulturowe przyjmowała jako coś oczywistego: „Byłam dzieckiem i niczego nie poddawałam w wątpliwość. Jeśli moja matka w palącym słońcu była zawinięta w materiał aż po czubek głowy, to było to tak samo normalne jak to, że inne młode kobiety kilka kroków dalej wykonywały tę samą pracę w przewiewnych koszulkach na ramiączkach"10. Imigranci, przeprowadzając się do miejsc oddalonych od swych domów rodzinnych nieraz o setki lub tysiące kilometrów zabierają ze sobą zawsze swój „dobytek kulturowy”, czyli wyuczone sposoby zachowywania się i porozumiewania z innymi, tradycje, przekonania i wierzenia religijne. Ich przybycie sprawiło, że kraje Europy Zachodniej stały się bardziej wielokulturowe i wieloreligijne ${ }^{11}$. Po latach zapamiętane z dzieciństwa Rielingshausen Hülja i jej siostra Esme nazwą prawdziwą ojczyzną ${ }^{12}$. Wspomnienia ojczystych stron ${ }^{13}$ uzmysławiały im sens podjęcia ryzyka ucieczki przed przymusowym małżeństwem ${ }^{14}$.

"Oni byli na zewnątrz, w Niemczech, w Szwabii, w Rielingshausen. Ja byłam uwięziona tu w środku, w drugiej Turcji” ${ }^{\prime 15}$ - ograniczenia ze strony rodziny

Kobiety od wieków obarczane były (a nieraz same obarczały się) ogromnymi obowiązkami domowymi. Poprzez ukierunkowanie energii kobiet na monotonne prace codzienne, tłumiono ich - na co wskazuje Besala - kreatywność i redukowano świat ich uczuć16. Christiane Klapisch-Zuber mówi wręcz, może przesadnie, o „unieruchomieniu ludzkiego ciała"17. Tendencje te widoczne są we wspomnieniach Kalkan. Hülja opisuje, że kiedy była dzieckiem w domu czekała na nią zawsze praca,

${ }^{9}$ Ibidem, s. 6.

${ }^{10}$ Ibidem, s. 7.

${ }^{11}$ K. Pędziwiatr, Od islamu imigrantów do islamu obywateli: muzutmanie w krajach Europy Zachodniej, Kraków 2007, s. 17.

${ }^{12}$ H. Kalkan, op. cit., s. 192.

${ }^{13} \mathrm{~W}$ tym miejscu warto odnieść się do rozważań na temat terminu 'Heimat' Anny Górajek (zob. A. Górajek, O wieloznaczności słowa Heimat - czyli o trudnościach interpretacyjnych pewnego pojęcia, [w:] Język - Literatura - Kultura. Konteksty Glottodydaktyczne, Płock 2011, s. 249-255).

${ }^{14}$ H. Kalkan, op. cit., s. 195n.

${ }^{15}$ Ibidem, s. 9.

16 J. Besala, op. cit., s. 332.

${ }_{17}$ Ch. Klapisch-Zuber, Rodzina i kobieta, [w:] Człowiek średniowiecza, (red.), J. Le Goff, Warszawa 2000, s. 384. 
podczas gdy jej brat mógł się bawić, kiedy chciał18. To było w jej rodzinie normalne bo on był chłopcem, a ona dziewczynkąa ${ }^{19}$. Według teologów islamskich przydział ról miedzy kobietami i mężczyznami ${ }^{20}$ miał wynikać z praw natury, czyli biologicznych i fizjologicznych różnic określających pozycje społeczne i wykonywane prace. W surze IV Koranu pojawia się duch egalitaryzmu, wszyscy muzułmanie są równi, a dobre kobiety także wstąpią do raju, jednak nagroda Ogrodu czeka według tych słów dopiero po śmierci (Koran IV). Hadisy Proroka zawierają myśl, że kobieta nie jest tworem równie doskonałym jak mężczyzna ${ }^{21}$. Zdaniem Besali nie da się ukryć, że świat koraniczny przenika duch skrajnego androginizmu, kultury patriarchalnej, a kobieta jest uprzedmiotowiona ${ }^{22}$. Kalkan wspomina metody wychowawcze stosowane w jej domu, dystansując się jednocześnie od takiego sposobu:

„Nie było to przyjemne, ale byłam przyzwyczajona do bicia. - Kto nie bije swoich dzieci, bije siebie samego - mówi porzekadło, którego matka chętnie używała. Najwidoczniej uważała, że nie da się inaczej wychowywać potomstwa, aby nie przyniosło wstydu w przyszłości"23.

Opisany przez Kalkan sposób wychowywania dzieci wpisuje się w długą tradycję. W X-XI wieku wychowywanie dzieci silną ręką zalecał poeta Abu Al-Ala al-Ma'arri, prawdopodobnie najbardziej dojrzały emocjonalnie twórca w okresie rozkwitu kultury arabskiej, stwierdzając, że należy bić swoje dzieci i uczyć je rozsądku, nie mówiąc, że są na wszystko za małe $^{24}$. Sura IV zezwala także na bicie nieposłusznych żon (Koran IV) ${ }^{25}$.

Kalkan opisuje także brak zainteresowania rodziców edukacją dzieci. Relacjonuje, że niejednokrotnie musiała zostawać w domu, mimo, że powinna i chciała iść do szkoły, gdyż lubiła się uczyć i nie chciała w przyszłości wykonywać takiej ciężkiej pracy jak jej matka ${ }^{26}$. W roku 1997 wśród obcokrajowców w Niemczech 78\% nie posiadało żadnych kwalifikacji za-

${ }^{18}$ Prowadzone w XX wieku badania wioski Hal wskazuja, że dziewczynki były uważane za gorsze od chłopców, od najmłodszych lat miały wiele obowiązków, a od dwunastego roku życia musiały już nakładać chusty i zasłaniać twarz (zob. J. Besala, op. cit., s. 412).

${ }^{19}$ H. Kalkan, op. cit., s. 9.

${ }^{20}$ W państwie Osmanów na kobietę spadło wiele skrajnie trudnych i wyczerpujących obowiązków, degradując niegdyś równorzędną mężczyźnie kobietę turecką (zob. J. Besala, op. cit., s. 412).

${ }^{21}$ J. Besala, op. cit., s. 353n.

${ }^{22}$ Ibidem, s. 356.

${ }^{23}$ H. Kalkan, op. cit., s. 9.

${ }^{24}$ J. Besala, op. cit., s. 393n.

${ }^{25}$ Koran (IV); J. Besala, op. cit., s. 353n.

${ }^{26}$ H. Kalkan, op. cit., s. 10, 11. 
wodowych ${ }^{27}$. Dotyczy to w większym stopniu kobiet niż mężczyzn. Tendencje, aby nie nauczać dziewczynek oraz że powinny albo leżeć w grobie albo wyjść za mąż widoczne są już w poradach dydaktycznych księcia z dynastii perskich Zijarydów dla syna o tym jak wychowywać córkę ${ }^{28}$. Kalkan wspomina, iż mimo, że znajdowała się w Niemczech to przez swoją rodzinę zmuszana była do życia według surowych i nie zawsze właściwych w odmiennej rzeczywistości zasad, których jej rodzice nauczyli się w Turcji:

„Słyszałam dobiegające z zewnątrz okrzyki mojego rodzeństwa. Bawili się radośnie w swojej dżungli. Oni byli na zewnątrz, w Niemczech, w Szwabii, w Rielingshausen. Ja byłam uwięziona tu w środku, w drugiej Turcji, którą moja matka stworzyła w naszym domu"29. Jak zaznacza Besala dotąd wśród talibów w Pakistanie i Afganistanie wymierza się kary chłosty za nauczanie dziewczynek ${ }^{30}$.

„[...] byłam jedyną dziewczynką w moim wieku, która [...] nosiła chustkę na głowie" ${ }^{\prime \prime 1}$ - chusta na głowie jako symbol zniewolenia, demonstracja, ochrona, wyraz religijności i osobowości

Skromność nakazuje kobiecie w Koranie Sura 24, wers 31. Kalkan w swojej książce zwraca jednak uwagę jak bardzo złożona może być kwestia noszenia przez kobietę chusty na głowie. Jako dziecko odbierała chustę jako symbol izolacji z grupy rówieśników:

„W podstawówce w Rielingshausen rzucałam się w oczy. Nie dlatego, że byłam jedyną Turczynką. W naszej miejscowości mieszkało pięć tureckich rodzin. Ale byłam jedyną dziewczynką w moim wieku, która od lata [od przejścia do trzeciej klasy - J. G.-A.] nosiła chustkę na głowie" ${ }^{\prime \prime 2}$.

Kalkan wspomina także reakcje Niemców na fakt noszenia chusty przez małą dziewczynkę. Niemcy bez złośliwości wyrażali swoje zdziwienie i pytali, czy jest żoną, a nie córką, co zdaniem Hülji musiało jej ojcem wstrząsnąć. Dzięki rozmowom z osobami o mniej radykalnym nastawieniu Kalkan zaczęła poddawać kwestię konieczności noszenia chusty w wątpliwość. Powoli budziła się w niej świadomość, że jej życie mogłoby wyglądać inaczej ${ }^{33}$. Nigdzie nie widać, aby Mahomet zdecydowanie

\footnotetext{
${ }^{27}$ K. Pędziwiatr, op. cit., s. 66.

${ }^{28}$ J. Besala, op. cit., s. 392.

${ }^{29}$ H. Kalkan, op. cit., s. 9.

${ }^{30}$ J. Besala, op. cit., s. 392.

${ }^{31}$ H. Kalkan, op. cit., s. 10.

${ }^{32}$ Ibidem, s. 10.

${ }^{33}$ Ibidem, s. 40.
} 
skłaniał kobiety do chowania się za zasłonami, jak to nastąpiło później ${ }^{34}$. Kalkan zauważa także, że w niektórych miejscach w Niemczech istniały zakazy dotyczące zakładania chust. Kiedy ojciec pojechał, aby zapisać córkę do szkoły w Beilstein, sekretarka dyrektora, obrzuciła dziewczynę wzrokiem i powiedziała, że chusta na głowie jest w tej szkole zabroniona, co przyczyniło się do uwolnienia Hülji od chusty ${ }^{35}$. Pomimo, iż sam Mahomet nie nakazywał trzymać kobiet $\mathrm{w}$ ukryciu ani za zasłonami, ale ten obyczaj stał się jednym z wyróżników kobiet w islamie. Od VII-VIII wieku bogate rody zaczęły izolować swoje kobiety, jeśli szanowane kobiety miały wyjść na ulicę ich obowiązkiem stało się chowanie twarzy, włosów i figury za zasłonami ${ }^{36}$.

Jako osoba dorosła Hülja zauważyła, że w niektórych przypadkach chusta na głowie może być wyrazem prawdziwej religijności kobiety, wynikiem poczucia ochrony przed natrętnymi mężczyznami:

„Esme tworzyła fantastyczny własny styl ubierania się. Elegancką modę zachodnią łączyła w wyrafinowany sposób z tradycyjną chustą na głowie. Wszystko było znakomicie dobrane kolorystycznie. Jej chusty robiły wrażenie nie tyle symbolu islamu, ile modnych barwnych zawojów. Aczkolwiek nie wolno jej było używać szminki, zgodnie z surowymi nakazami religii ${ }^{37}$, robiła to z perfekcją specjalistki od makijażu. W tym układzie chusta na głowie nie sprawiała wrażenia symbolu uciśnionej muzułmanki. Była raczej wyrazem jej złożonej osobowości"38.

Jednocześnie noszenie chusty w Niemczech, niezależnie od motywacji, nie zawsze spotykało się ze zrozumieniem. W Niemczech spotkać się można z antypatią do kobiet noszących chusty, określaną niekiedy jak 'hidżabofobią.' Kobiety noszące publicznie chusty, niezależnie od ich przekonań i kwalifikacji zawodowych doświadczają nieraz dyskryminacji, na przykład w miejscu pracy. Dotyczy to także osób, które dobrowolnie przeszły na islam ${ }^{39}$. We wrześniu 2003 roku dyrekcja szkoły w Stuttgarcie zabroniła nauczycielce przychodzenia na lekcje w chuście. Niemiecki sąd najwyższy zdecydował, że ostateczną decyzję w tego typu sprawach powinny mieć władze lokalne. Do początku kwietnia 2004 roku sześć landów wprowadziło regulacje zakazujące noszenia hidżabów w szkołach,

${ }^{34}$ J. Besala, op. cit., s. 362.

${ }^{35}$ H. Kalkan, op. cit., s. 41.

${ }^{36}$ J. Besala, op. cit., s. 370n.

37 Prorok nie zgadzał się na zwyczaje poprawiania urody wśród beduinek, takie jak tatuowanie, wyrywanie włosów czy robienie odstępów między zębami, gdyż stanowi to próbę zmienienia tego, co stworzył Bóg (zob. J. Besala, op. cit., s. 362).

${ }^{38}$ Kalkan, op. cit., s. 201.

${ }^{39}$ H. Haruna, Rabea sucht einen Job. Welchen Klischees gläubige Muslime bei der Bewerbung begegnen, „Die Zeit” 2012, nr 23, www. zeit.de/2012/23/C-Jobboerse (27 listopada 2012). 
między innymi Badenia-Wirtembergia, Bawaria i Hesja ${ }^{40}$. Kiedy po zamordowaniu na przełomie 2004 i 2005 przez własne rodziny kilku młodych Turczynek, które nie chciały już pod przymusem wychodzić za mąż albo żądały rozwodów, segregacja muzułmańskich kobiet stała się tematem wielu dyskusji, wówczas noszenie chusty w takiej atmosferze było odbierane przez otoczenie jako demonstracja ${ }^{41}$.

„Nie musisz być koniecznie muzułmaninem, aby być dobrym człowiekiem”"42 - niemiecka nauczycielka jako wzór kobiety

Hülja jako dziecko doświadczyła zainteresowania i zrozumienia ze strony nauczycielki szkolnej, która potrafiła z całą klasą przyjść do domu uczennicy, dzięki czemu brak zainteresowania nauką ze strony matki stawał się tym bardziej widoczny. Matka nie chciała sama rozmawiać z nauczycielką swojej córki: „Mimo, że mieszkała od dwunastu lat w Niemczech, znała tylko kilka podstawowych słów po niemiecku. Nie była ani razu na wywiadówce $\mathrm{w}$ naszej szkole ${ }^{\prime \prime 3}$. Imigracyjne rodziny żyjące w Niemczech, których członkowie mieli ograniczony dostęp do edukacji często nie przywiązują wagi do poziomu wykształcenia swoich dzieci, nie potrafią ich motywować do nauki. Dodatkowym problemem jest słaba znajomość języka niemieckiego ${ }^{44}$. Hülja już jako dziecko była świadoma jak jej matka i jej poglądy mogą być postrzegane w niemieckiej rzeczywistości: „Miałam co prawda dopiero dziewięć i pół roku, ale wiedziałam, że nie mogę absolutnie żądać, aby zmierzyła się [matka] z panią Gilles przed całą klasą. Strasznie by się ośmieszyła" ${ }^{\prime \prime 5}$.

O ile Mahomet zalecał znajdowanie dobrych cech w każdym muzułmaninie i muzułmance i wzywał do zaniechania pogardy muzułmanów między sobą ${ }^{46}$, o tyle niemiecka nauczycielka była osobą odważną i stanowczą, a także uważała, że bycie dobrym człowiekiem nie jest związane $z$ konkretną religią. Swoim zachowaniem udowadniała, jak to rozumiała ${ }^{47}$.

Hülja z powodu stanowiska matki była izolowana z grupy rówieśników: jako jedyna z klasy nie mogła pojechać na zieloną szkołę, podczas lekcji pływania, czekała na trybunach i czuła się wyłączona ze wspólnoty

\footnotetext{
${ }^{40}$ K. Pędziwiatr, op. cit., s. 68.

${ }^{41}$ H. Kalkan, op. cit., s. 202.

${ }^{42}$ Ibidem, s. 12.

${ }^{43}$ Ibidem, s. 11.

${ }^{44}$ K. Pędziwiatr, op. cit., s. 67.

${ }^{45}$ H. Kalkan, op. cit., s. 13.

${ }^{46}$ J. Besala, op. cit., s. 366.

${ }^{47}$ H. Kalkan, op. cit., s. 12.
} 
kolegów i koleżanek ze szkoły, nie mogła jeździć na rowerze i jako jedyna ze szkoły nie zdała na kartę rowerową ${ }^{48}$. Odwrotnie do fali emancypacji kobiet w Europie po rewolucji francuskiej dekrety sułtańskie wprowadzały liczne zakazy i ograniczenia dla kobiet. Dama turecka mogła od 1790 roku pojawiać się tylko cztery razy w tygodniu poza domem, a w 1807 wprowadzono całkowity zakaz pokazywania się kobietom, nawet $w$ towarzystwie męża lub ojca ${ }^{49}$. Hülja wielokrotnie była wyłączona ze społeczności klaso$w^{j} j^{50}$ nie ze względu na brak akceptacji przez Niemców inności, ale brak chęci asymilacji ze strony własnej rodziny.

Zderzenie cywilizacji to według Besali również zderzenie dwóch światów postrzegania i okazywania uczuć51. Nauczycielka, świadoma uczuć dziewczynki wyłączonej z życia klas z powodu przekonań religijnych matki, przyszła do domu, aby przekonać rodziców do zielonej szkoły, jednak matka myślała przede wszystkim o tym, aby okazać się dobrą gospodynią ${ }^{52}$. Powodem napięć i zderzeń cywilizacji zdają się być, zdaniem Besali, nie tylko różnice religijne, dżihad czy poczucie zagrożenia ze strony świata zachodniego, ale także stosunek do uczuć i relacje kobiet z mężczyznami, stosunek do partnerstwa i wolności kobiety, do poszanowania wzajemnych uczućs ${ }^{3}$. Refleksja Hülji na temat zderzenia postaw dwóch kobiet jest niezwykle przygnębiająca:

Miałam dziewięć lat i chodziło tylko o obóz szkolny. Ale niemiecki matki był zbyt słaby, aby mogła porozmawiać na ten temat z otwartą na świat nauczycielką. Pani Gilles wychodziła smutna. Byłam jeszcze za mała, aby móc się przyznać, że chciałabym mieć taką matkę jak ona, taką, która byłaby dla mnie wzorem, która jest samodzielna, pewna siebie, ma swoje zdanie i potrafi je poprzeć argumentami ${ }^{54}$.

Bardzo gorzka jest obserwacja dziewczyny na temat matki, która nie jest dla niej wzorem, tak jak może być wykształcona i pełna empatii nauczycielka:

„Jako turecka dziewczyna musiałam zawsze okazywać respekt wobec matki. Przychodziło mi to z trudem, bo na ten szacunek nie zasługiwała" ${ }^{\prime 55}$.

\footnotetext{
${ }^{48}$ Ibidem, s. 13n.

${ }^{49}$ J. Besala, op. cit., s. 416.

${ }^{50}$ H. Kalkan, op. cit., s. 17.

${ }^{51}$ J. Besala, op. cit., s. 367.

${ }^{52}$ H. Kalkan, op. cit., s. 15, 16.

53 J. Besala, op. cit., s. 364.

${ }^{54}$ H. Kalkan, op. cit., s. 16.

55 Ibidem, s. 60n.
} 
"Chęć odrzucenia przeze mnie wiary matki była tak silna jak nienawiść, którą do niej czułam" ${ }^{\prime 56}$ - religia imigrantów i religia obywateli

W europejskim islamie zaobserwować można zmiany związane z tym, że jest on w chwili obecnej coraz silniej związany z drugim pokoleniem imigrantów, osobami urodzonymi w Europie. Islam wyznawany przez nich różni się od islamu ich rodziców ${ }^{57}$. Kalkan opisuje działania matki, która mieszkając w Niemczech nie chciała zaakceptować otaczającej ją rzeczywistości. Hülja wspomina, że jej brat został okaleczony z powodu chorych koncepcji matki, której serce biło w rytm tradycji Azji Mniejszej, podczas gdy jej dzieci dorastały jako Europejczycy. Radykalne zachowania matki przyczyniały się do ukształtowania przez Hülję jej własnych przekonań. Zanim została zmuszona do pójścia do szkoły koranicznej określiła własny stosunek do religii: „Chęć odrzucenia przeze mnie wiary matki była tak silna jak nienawiść, którą do niej czułam. Jak mogła robić takie rzeczy swoim dzieciom? Jeśli kiedykolwiek będę miała dzieci, nie będę ich tak traktować. Będą miały możliwość własnego wyboru"58. Dziewczyna uświadamia sobie boleśnie różnice między sytuacją swoją i swoich rówieśników w Niemczech, którzy w czasie wakacji wypoczywali i jak określa Kalkan przewracali się w miękkich łóżkach na drugi bok, podczas gdy ona jak katarynka powtarzała sury, których nigdy nie rozumiała. Przebywając w szkole koranicznej w Turcji Hülja marzyła o powrocie do Niemiec, w marzeniach chodziła tam do szkoły, dostawała dobre oceny z klasówek, była chwalona za osiągnięcia, przychodziła do domu i bawiła się z rodzeństwem. To był czas, w którym czuła się sobą ${ }^{59}$.

„Oczywistym było, że wiedziałyśmy w tym czasie więcej o Niemczech niż matka" ${ }^{\prime \prime 0}$ - kompetencje kulturowe imigrantów

Na czynnik przedmigracyjny składają się elementy zabierane przez imigrantów w nowe miejsce, m.in. religia, wierzenia, zwyczaje i język, a od bogactwa tego bagażu zależą zmiany w dotychczasowej praktyce religijnej i to, jak szybko będzie przebiegała ich integracja ze społeczeństwami przyjmującymi ${ }^{61}$. Matka Hülji zamknięta w Niemczech na własne życzenie w swoim tureckim świecie miała całkiem błędne wyobrażenia

\footnotetext{
${ }^{56}$ Ibidem, s. 21.

${ }^{57}$ K. Pędziwiatr, op. cit., s. 204n.

${ }^{58}$ H. Kalkan, op. cit., s. 21.

${ }^{59}$ Ibidem, s. 24, 26.

${ }^{60}$ Ibidem, s. 43.

${ }^{61}$ K. Pędziwiatr, op. cit., s. 18.
} 
o kraju w którym żyła i obyczajach w nim panujących. Posiadanie kart na przykład było według niej jednoznaczne $z$ hazardem ${ }^{62}$. Młodzi muzułmanie w Niemczech na ogół oglądają natomiast te same programy telewizyjne, czytają te same gazety i słuchają tych samych radiostacji co ich niemuzułmańscy rówieśnicy ${ }^{63}$. Dzieci w oczywisty sposób, nawet mimo zakazów i ograniczeń wprowadzanych przez rodzinę, wiedziały więcej o Niemczech niż matka, chociaż także one przekonywały się wielokrotnie o różnicach. Hülja wspomina swoją pierwszą pracę, w której miała jeszcze problemy z niemieckim obyczajami przy stole i nie zawsze udawało się jej odpowiednio do niego nakryć64. Osoby przybywające do Europy Zachodniej w ramach programów rekrutacyjnych spoza byłych terytoriów kolonialnych charakteryzowały się mniejszymi kompetencjami kulturowymi niż imigranci postkolonialni ${ }^{65}$. W przeciwieństwie do matki ojciec Hülji, który jako młody chłopak mieszkał przez kilka lat u niemieckiej rodziny, przystosował się do niemieckiej rzeczywistości:

Pracował na akord, dzwonienie zegara odmierzającego czas w pracy ustalało przebieg jego dnia, a nie modlitwy. Przystosował się do niemieckich warunków i szybko nauczył języka. - Niewierny! - tak obrażała młoda żona swego po niemiecku żyjącego męża ${ }^{66}$.

Muzułmanie urodzeni w Europie rozróżniają to, co należy do sfery religijnej od tego, co należy do etniczności ${ }^{67}$, natomiast w przypadku matki Hülji decydujące były w każdej sferze życia nakazy religijne. Nie podejmowała ona próby wyjaśnienia czegokolwiek lub refleksji nad sytuacją.

„[...] nie rozumiała, co mówią do niej urzędnicy. Ale o to nikt się nie martwił"68 - prawo do pozostawania w Niemczech

Według relacji Kalkan o prawie do pozostawania w Niemczech nie decydowały kompetencje kulturowe ani stopień asymilacji lub integracji. Hülja opisuje jak bardzo przewrotne okazało się życie. Pomimo, że ojciec integrował się, znał język to właśnie jego odesłano po latach z Niemiec: „Republika Federalna Niemiec wydaliła go poza swoje granice. [...] Zgod-

\footnotetext{
${ }^{62}$ H. Kalkan, op. cit., s. 42.

${ }^{63}$ K. Pędziwiatr, op. cit., s. 201.

${ }^{64}$ H. Kalkan, op. cit., s. 43, 44.

${ }^{65}$ K. Pędziwiatr, op. cit., s. 26 n.

${ }^{66}$ H. Kalkan, op. cit., s. 47.

${ }^{67}$ K. Pędziwiatr, op. cit., s. 205n.

${ }^{68}$ H. Kalkan, op. cit., s. 62.
} 
nie z ustawą o cudzoziemcach tata musiał natychmiast opuścić Niemcy. Wsadzono go do samolotu do Turcji. Po dwudziestu trzech latach, które tu przeży1"69. Jednocześnie prawo pobytu w Niemczech otrzymywały osoby, które według Kalkan nie integrowały się w niemieckim społeczeństwem i nie uczyły języka niemieckiego, tak jak jej matka, która co dwa lata bez kłopotu dostawała przedłużenie pozwolenia na pobyt, przy czym nie mogła nawet sama pójść do Urzędu do Spraw Cudzoziemców, ponieważ nie rozumiała, co mówią do niej urzędnicy: „Ale o to nikt się nie martwił. [...] Ostatecznie jej poglądy na temat wszystkiego co jest haram [zabronione], nikogo nie interesowały"70. Zdaniem Besali nadmiar regulacji prawnych lub religijnych na ogół blokuje żywiołowe wyrażanie uczuć, a staranne instrukcje obsługi życia są wyrazem niedowierzania w naturalne dobre uczucia kierujące człowiekiem ${ }^{71}$.

„Myślała prawdziwie po niemiecku, jak oszczędna Szwabka. Ale matki to nie cieszyło. Przeciwnie" ${ }^{\prime \prime 2}$ - proces integracji

Popularny we współczesnych mediach koncept migracyjny zakłada nie asymilację, lecz integrację, czyli proces dwukierunkowy, zmiany społeczności migracyjnych i społeczeństw przyjmujących ${ }^{73}$. Matka Hülji natomiast nie tylko sama nie chciała się integrować, ale także widziała w kulturze niemieckiej zagrożenie dla swoich dzieci: „Esme była taka rozsądna. Myślała prawdziwie po niemiecku, jak oszczędna Szwabka. Ale matki to nie cieszyło. Przeciwnie" ${ }^{\prime 74}$. Hülja zastanawia się, co musiało czuć jej rodzeństwo pozbawione nagle możliwości życia w znanej dla siebie niemieckiej rzeczywistości: „Oboje byli tu wychowani, a ta kobieta [tak Hülja nazywa matkę - J. G.-A.] brutalnie wyrwała obie te istoty z ich świata"75. Kalkan podkreśla, że mieszkali oni w Niemczech i dzięki kolegom ze szkoły i przyjaciołom wiedzieli, że anatolijskie tradycje niewiele w Europie znaczą ${ }^{76}$.

\footnotetext{
${ }^{69}$ Ibidem, s. 62.

${ }^{70}$ Ibidem, s. 12

${ }^{71}$ J. Besala, op. cit., s. 365.

${ }^{72}$ H. Kalkan, op. cit., s. 77.

${ }^{73}$ K. Pędziwiatr, op. cit., s. 197.

${ }^{74}$ H. Kalkan, op. cit., s. 77.

${ }^{75}$ Ibidem, s. 77.

${ }^{76}$ Ibidem, s. 78.
} 


\section{„[...] wszyscy Niemcy bardzo się o mnie troszczyli i byli niezwykle delikatni" - postawa społeczności przyjmującej}

Do czynników pomigracyjnych zaliczyć można m.in. religię lub religie wyznawane przez mieszkańców państwa przyjmującego, praktykowane w nim zwyczaje, spuściznę kulturową i ramy polityczne, a także charakter reakcji społeczeństwa autochtonicznego wobec cudzoziemców ${ }^{77}$. Hülja stwierdza, że mimo, iż urodziła się i wychowywała w Niemczech, obowiązywały ją tureckie zasady. Z psychologicznego punktu widzenia w tej sytuacji możliwe były dwie drogi; załamania, depresji, rezygnacji oraz walki. Kalkan wybrała tę drugą drogę. W związku z tym kiedy dziewczyna chciała się wyprowadzić od matki zmuszona była zwrócić się o pomoc do niemieckich urzędów. W samym Stuttgarcie co miesiąc dziesięć do dwunastu dziewczyn zwraca się do Urzędu do Spraw Młodocianych o ochronę przed swoją rodziną. Według statystyk miejskich co czwarty mieszkaniec Stuttgartu nie urodził się w Niemczech albo ma rodziców pochodzących z zagranicy, tak jak było w przypadku Kalkan. Na podstawie paszportu można twierdzić, że była cudzoziemką, ale nikt jej tak nie traktował, a wszyscy Niemcy bardzo się o nią według jej słów troszczyli i byli niezwykle delikatni ${ }^{78}$. W wyniku procesów migracyjnych po drugiej wojnie światowej w Europie Zachodniej mieszka około 14 milionów muzułmanów, a islam jest drugą pod względem liczny wiernych religią Europy $^{79}$.

„Nie byłam już Turczynką i nie czułam się nią"80 - niemieckie obywatelstwo

Proces naturalizacji najwolniej przebiega $\mathrm{w}$ krajach, gdzie największą popularnością cieszy się koncepcja prawa krwi, jak Niemcy, Austria i Szwajcaria. W Niemczech do roku 2000 obowiązywało prawo krwi ${ }^{81}$. Najsłabsza tożsamość narodowa wśród społeczności imigranckich cechuje przedstawicieli społeczności tureckiej w Niemczech, których tylko 8\% czuje się Niemcami ${ }^{82}$. Kalkan postrzega Niemcy jako swoją ojczyznę, która dała jej upragnioną wolność: „Głos wewnętrzny podpowiadał mi szeptem:

\footnotetext{
${ }^{77}$ K. Pędziwiatr, op. cit., s. 19.

${ }^{78}$ H. Kalkan, op. cit., s. 84n.

${ }^{79}$ K. Pędziwiatr, op. cit., s. 11, 20n.

${ }^{80}$ H. Kalkan, op. cit., s. 97.

${ }^{81}$ K. Pędziwiatr, op. cit., s. 27, 35n.

${ }^{82}$ Ibidem, s. 202.
} 
tam, gdzie możesz być wolna jest twój dom”83. Do Turcji postanowiła się wybrać dopiero kiedy będzie Niemką, gdyż dopiero wtedy krewni matki nie będą mogli jej nic zrobićs ${ }^{84}$ Integracja na poziomie tożsamościowym, kojarzona z najbardziej zaawansowanym stopniem włączenia cudzoziemców do nowych struktur społecznych, oznacza odczuwanie poczucia przynależności do nowych społeczeństw, państw, narodów ${ }^{85}$. Stanowisko Hülji w związku z obywatelstwem jest bardzo jednoznaczne. Chwilę, w której dostała niemiecki paszport uważa za moment wyzwolenia. Stanowczo mówi: „Nie byłam już Turczynką i nie czułam się nią”86.

„Byłam częścią społeczeństwa, w którym żyłam”87 - życie na pograniczu kultur

Islam nie jest obecnie w Europie tylko religią imigrantów, lecz także w znacznej mierze obywateli, osób, które urodziły się w Europie ${ }^{88}$. Kalkan przeprowadza trafną analizę sytuacji, w jakiej znajdują się dzieci obcokrajowców:

[...] chcemy kochać naszych rodziców, ale nie pozwolimy sobie narzucić konserwatywnego sposobu życia przez tych, którzy nie dorastali - jak my - w niemieckiej kulturze. Ucząc się w przedszkolach, szkołach, placówkach kształcenia zawodowego, my, dzieci, imigrantów znajdujące się na pograniczu kultur, musiałyśmy znaleźć własną drogę życiową ${ }^{89}$.

Kalkan została przez zarząd miasta zatrudniona w „Forum Kultur”, którego zadaniem było propagowanie wśród mieszkańców Stuttgartu organizacji imigrantów oraz artystów pochodzących z innych krajów, którzy znaleźli dla siebie dom w Stuttgarcie i organizowali koncerty, imprezy i festiwale ${ }^{90}$. Jednocześnie Kalkan stwierdza otwarcie:

Byłam teraz Niemką i myślałam jak Niemka. Dlaczego miałabym działać inaczej? Tylko dlatego, że miałam tureckich rodziców? Przecież to nonsens. Byłam częścią społeczeństwa, w którym żyłam ${ }^{91}$.

\footnotetext{
${ }^{83}$ H. Kalkan, op. cit., s. 88.

${ }^{84}$ Ibidem, s. 94.

${ }^{85}$ K. Pędziwiatr, op. cit., s. 198.

${ }^{86}$ H. Kalkan, op. cit., s. 97.

${ }^{87}$ Ibidem, s. 115.

${ }^{88}$ K. Pędziwiatr, op. cit., s. 11.

${ }^{89}$ H. Kalkan, op. cit., s. 113.

${ }^{90}$ Ibidem, s. 114.

${ }^{91}$ Ibidem, s. 115.
} 
„Ustawa nie przewiduje środków prawnych..." ${ }^{\prime 22}$ - niemieckie urzędy wobec cudzoziemców

Kalkan ukazuje ciepły i przychylny obraz ludzi otwartych na sytuację osób konfrontowanych z takimi problemami jak ona sama. Jednocześnie przedstawiony przez nią obraz urzędów mających za zadanie pomagać obcokrajowcom wydaje się mniej optymistyczny. Nie zawsze jest to złe nastawienie, czasami wynika to $\mathrm{z}$ braku zaangażowania. $\mathrm{W}$ prowadzonej jesienią 2010 roku kilkutygodniowej debacie o antymuzułmańskiej książce Thilo Sarrazina, ujawniły się pokłady ksenofobii istniejące w warstwach średnich niemieckiego społeczeństwa ${ }^{93}$. Urzędnicy niemieccy cechują się według Kalkan znaczną niewiedzą w kwestii prawdziwej sytuacji imigrantów. Urząd do Spraw Cudzoziemców stwierdził, że jeśli sprawa wywiezionej do Turcji dziewczyny dotyczy osoby pełnoletniej to to nie jest jego problem, lecz sprawa rodziny, wobec czego nie można w żaden sposób pomóc. Kalkan nie kryje swojego rozczarowania, kiedy patrzyła na twarze niemieckich kobiet, na których nie gościł nawet ślad zainteresowania, a jej sprawa była im obojętna. Podobną porażką była wizyta u pełnomocnika do spraw kobiet, u pełnomocnika do spraw integracji w Stuttgarcie, w Urzędzie do Spraw Cudzoziemców. W referacie do Spraw Migracji wskazano odpowiednie prawa, które mogą pomóc ${ }^{94}$, jednak w pedantyczny wprost sposób obliczano czas nauki, w wyniku czego Esme została wykluczona z ojczyzny z powodu pół roku ferii szkolnych. Na argument, że ojczyzną Esme są Niemcy, usłyszała odpowiedź, że prawo jest prawem ${ }^{95}$. Także kierownik szkoły, który wysłał brata Hülji do szkoły integracyjnej oświadczył, że musi przestrzegać przepisów ${ }^{96}$. Kalkan ukazuje negatywny obraz Urzędu do Spraw Cudzoziemców: „Jednak urzędnicy albo byli na urlopach i nie odbierali telefonów, albo uczestniczyli w niekończących się naradach. Oczywiście, jeśli nie mieli akurat przerwy na posiłek"97. Pani z Referatu do Spraw Migracji wysłuchała cierpliwie historii, jednak ostatecznie stwierdziła: „Ustawa nie przewiduje środków prawnych wobec wymuszonego małżeństwa [...]”98. Kalkan gorzko podsumowuje: „Nie ma małżeństw pod przymusem? Urzędnicy stuttgarckiego Urzędu do Spraw Cudzoziemców powinni poznać życie codzienne w Turcji, a nie tylko wy-

${ }^{92}$ Ibidem, s. 114.

93 P. Buras, Muzutmanie i inni Niemcy. Republika berlińska wymyśla się na nowo, Warszawa 2011, s. 15.

\footnotetext{
${ }_{94}$ H. Kalkan, op. cit., s. 121 n.

${ }_{95}$ Ibidem, s. 124.

${ }_{96}$ Ibidem, s. 132.

${ }^{97}$ Ibidem, s. 136.

98 Ibidem, s. 144.
} 
poczywać na plażach w kurortach nad Morzem Śródziemnym!"’99. Jednocześnie porwania kobiet należą do rzeczywistości, czego wyrazem może być wiersz o losie muzułmanki tureckiej napisany w XX wieku przez muzułmankę turecką ${ }^{100}$.

$$
\begin{gathered}
\text { "Przecież wszyscy Niemcy piją kawę̨"101 - stereotypy na temat } \\
\text { Niemców }
\end{gathered}
$$

Z przeprowadzonych na początku XXI wieku badań wynika, że w Niemczech $80 \%$ obywateli kojarzy „islam” z terroryzmem i prześladowaniem kobiet ${ }^{102}$. Także obraz Niemiec i Niemców u części Turków opiera się według Kalkan na błędnych wyobrażeniach i stereotypach. Matka Hülji, podejmując nauczycielkę powiedziała do córki: „Zapytaj ją, czy chce kawy. Przecież wszyscy Niemcy piją kawę"103. Podobnie niepełny lub fałszywy obraz mają Turcy mieszkający w Turcji: „Matka Mehmeda długo wypytywała mnie o Niemcy. Chciała wiedzieć, czy te historie z nazistami rzeczywiście były takie straszne? Ani ona, ani jej mąż nie byli nigdy w Niemczech. [...] Ich obraz Niemiec ukształtowany był głównie przez tendencyjne informacje przekazywane w tureckiej prasie codziennej"104. Trudno jest stworzyć płaszczyznę porozumienia i podstawy do integracji w oparciu o stereotypy i uprzedzenia.

„Daj swoim dzieciom korzenie, kiedy są małe i skrzydła, kiedy są duże"105 - perspektywy integracji

Optymizmem napawać może fakt, że pod wpływem uporu dzieci matka powoli zmieniła poglądy:

Zanim rodzice wydadzą na świat dzieci, powinni mieć możliwość nauczyć się, jak je wychowywać - rzuciła mimochodem. Dla kobiety z gór Anatolii taka myśl oznaczała niemal rewolucję. Tam gdzie mama dorastała, dzieci rodziły się po to, żeby służyć rodzicom i zapewnić im byt na starość. Uznanie, że każdy człowiek ma własną osobowość i nie jest tylko członkiem ludzkiego stada, było dla tych górali nie do pojęcia. Przejście od ciasnych ram wiejskich do szerokich horyzontów cywilizacji zachodniej musiało prowadzić do konfliktu"106.

\footnotetext{
${ }^{99}$ Ibidem, s. 171n.

100 J. Besala, op. cit., s. 354.

${ }^{101}$ H. Kalkan, op. cit., s. 16.

102 K. Pędziwiatr, op. cit., s. 228.

${ }^{103}$ H. Kalkan, op. cit., s. 16.

104 Ibidem, s. 173.

105 Ibidem, s. 205.

106 Ibidem, 204.
} 
Imigranci muzułmańscy przyjeżdżający po II wojnie światowej przeprowadzali się nie tylko $\mathrm{z}$ jednego kraju do drugiego, $\mathrm{z}$ jednego kontynentu na drugi, ale także często ze wsi i małych miasteczek do wielotysięcznych lub wielomilionowych miast ${ }^{107}$. Ich dzieci nie tylko rodziły się i wychowywały w Europie, ale także przeważnie w mniejszych lub większych miastach. Kalkan analizuje przyczyny konfliktu między pokoleniem rodziców, żyjącym według tradycyjnych zasad i dzieci, wzrastających w Niemczech:

„Nasze oburzenie, oburzenie dzieci imigrantów, pokazywało naszym rodzicom wyrosłym w Turcji, jak bardzo różnił się ich świat od naszego. Wielu z nich reagowało, jak nasza matka, bezlitosną surowością, mając nadzieję, że w ten sposób uratują swoje ideały w nowoczesnym świecie. Mimo tego odczuwali, że tracą szacunek swoich dzieci, dla których świat dawnych wartości stał się anachronizmem"108.

Z perspektywy człowieka dorosłego i dojrzałego Kalkan szuka przyczyn postępowania swojej matki, a jednocześnie przygląda się motywacjom działań społeczności imigrantów, dostrzegając różnicę pomiędzy pierwszym i drugim pokoleniem imigrantów: „Matka nie była w stanie dać nam, czworgu dzieci, moralnego oparcia, siły, współczucia, troskliwości czy po prostu miłości. Nigdy nie nauczyła się, po co jest to potrzebne dorastającemu człowiekowi, bo nigdy nie miała ku temu okazji. Była surowo wychowana w Turcji i trzymała się tego, co uważała za wiarę. A poza tym był to jedyny łącznik z rodzina, którą pozostawiła w Turcji, gdy przeniosła się do Niemiec"109.

\section{Wnioski}

Podsumowując stwierdzić można, że Hülja Kalkan w swojej książce "Chciałam być tylko wolna. Moja ucieczka przed przymusowym ślubem” przedstawia pozytywny obraz ludzi żyjących w Niemczech - ludzi otwartych, wyrozumiałych, chętnych do pomocy. Jednocześnie ukazuje nie zawsze pozytywny obraz instytucji, w których ważniejsze okazują się przepisy niż ludzkie odruchy. Książka Kalkan to nie tylko wzruszający subiektywny zapis przeżyć związanych z przymusowym małżeństwem, ale także obserwacje dotyczące Niemiec i Niemców. Kalkan analizuje postawy imigrantów, konsekwencje funkcjonowania stereotypów, istnie-

\footnotetext{
107 K. Pędziwiatr, op. cit., 207.

${ }^{108}$ H. Kalkan, op. cit., s. 205.

109 Ibidem, s. 205.
} 
nia ze sobą i obok siebie różnych kultur i religii, współistnienia kultur i tworzenia się społeczeństw równoległych, złożoność kwestii noszenia hidżabu, wzorce dla młodych ludzi, kwestię religii imigrantów i religii obywateli oraz kompetencji kulturowych imigrantów, ukazuje postawę społeczeństw przyjmujących, życie na pograniczu i perspektywy integracji. Optymizmem napawać może spojrzenie Kalkan w przyszłość: „Chciałam, aby kiedyś moje dzieci przekazały następnym pokoleniom te ideały tolerancji, równości, uczciwości i wierności"110.

\section{Zusammenfassung}

Das Buch „Ich wollte nur frei sein. Meine Flucht vor der Zwangsehe" von Hülja Kalkan - einer jungen Deutschen türkischer Abstammung, ist nicht nur ein erschütterndes persönliches Zeugnis der Erlebnisse und Erfahrungen, die mit der Zwangsehe verbunden sind, die auch im 21. Jahrhundert immernoch ein relevantes Thema ist, sondern auch aufschlussreiche Bemerkungen über Deutschland und die Deutschen, das Überlegen über das Phänomen der Immigration und Integration. Kalkan analysiert Stellungnahmen der Immigranten, Folgen des Funktionierens von Stereotypen, Leben mit und nebeneinander, Koexistieren der Kulturen und Entstehen der parallelen Gesellschaften in Deutschland. Sie beschreibt die Komplexität der Frage des Kopftuches, die Bedeutung der positiven Muster für Jugendliche, Frage nach der Religion der Immigranten und der Religion der Bürger. Sie betont die Bedeutung der kulturellen Kompetenz der Immigranten, die Stellung der Annahmegesellschaften der Immigranten gegenüber, sowie das Leben an der Grenze von Kulturen und Perspektiven der Immigration in Deutschland.

110 Ibidem, s. 205. 